\title{
PERAN PEKERJA SOSIAL DALAM PELAYANAN SOSIAL BAGI PMKS YANG TERDAMPAK PSBB DI GOR TANAH ABANG JAKARTA PUSAT
}

\author{
Dewi Kartikawati \\ Universitas Binawan \\ Email: dewikartika@binawan.ac.id
}

\begin{abstract}
Abstrak
Penelitian ini bertujuan untuk mengetahui pelaksanaan pelayanan sosial bagi PMKS yang terdampak PSBB di GOR Tengsin Jakarta Pusat, dan peran pekerja sosial dalam pelayanan sosial bagi PMKS setelah diberlakukannya status pembatasan sosial berskala besar (PSBB) di GOR Karet Tengsin DKI Jakarta. Penelitian ini menggunakan pendekatan kualitatif dengan metode deskriptif. Subjek penelitian ini adalah pekerja sosial yang bertugas di GOR Karet Tengsin Jakarta Pusat. Pengumpulan data dilakukan dengan menggunakan teknik observasi, wawancara, dan dokumentasi. Hasil penelitian menunjukkan bahwa pelaksanaan pelayanan terhadap PMKS dilakukan melalui empat tahap, yaitu penjangkauan, pemeriksaan kesehatan, assesment dan pemberian pelayanan sosial lanjutan sesuai dengan kebutuhan PMKS. Peran pekerja sosial dalam pelayanan sosial bagi PMKS terdampak PSBB ini antara lain sebagai advocate, counselor, mediator, educator, case manager, fasilitator dan experts yaitu tenaga ahli dalam membantu menentukan layanan yang sesuai dengan kebutuhan klien. Faktor pendukung pekerja sosial dalam menjalankan perannya yaitu adanya rasa tanggungjawab sebagai pekerja kemanusiaan, dan adanya dukungan dari institusi Kementerian Sosial dan Dinas Sosial Provinsi DKI Jakarta. Faktor penghambat dalam melaksanakan peran pekerja sosial yaitu adanya kekhawatiran tertular covid-19, ketidaksiapan institusi pelayanan dalam menerima klien.
\end{abstract}

Kata Kunci: COVID-19, Peran Pekerja Sosial, PSBB, PMKS.

\begin{abstract}
This study aims to determine the implementation of social services for PMKS who are affected by PSBB at the Tengsin Sports Hall, Central Jakarta, and the role of social workers in social services for PMKS after the imposition of large-scale social restrictions (PSBB) at the Karet Tengsin Sports Hall, DKI Jakarta. This research uses a qualitative approach with descriptive methods. The subjects of this study were social workers who served at the Tengsin Rubber Sports Center, Central Jakarta. Data collection was carried out using observation, interview, and documentation techniques. The results showed that the implementation of services for PMKS was carried out through four stages, namely outreach, health checks, assessment and provision of advanced social services according to PMKS needs. The roles of social workers in social services for PMKS affected by the PSBB include, among others, as advocates, counselors, mediators, educators, case managers, facilitators and experts, namely experts in helping determine services according to client needs. Supporting factors for social workers in carrying out their roles are a sense of responsibility as humanitarian workers, and the support from the Ministry of Social institutions and the DKI Jakarta Provincial Social Service. The inhibiting factors in carrying out the role of social workers are the concern of contracting co-19, the unpreparedness of service institutions in accepting clients.
\end{abstract}

Keywords: COVID-19, The Role of Social Workers, Large-Scale Social Restrictions, Personnel Social Welfare Problems. 


\section{A. PENDAHULUAN}

Peraturan Menteri KesehatanNomor 9 Tahun 2020 tentang Pedoman Pembatasan Sosial Berskala Besar Dalam Rangka Percepatan Penanganan Corona Virus Disease 2019 dan PeraturanGubernur DKI Jakarta Nomor 33 Tahun 2020 tantang pelaksanaan Pembatasan Sosial Berskala Besar dalam Penanganan Corona Virus Disease 2019 (COVID-19) di Provinsi Daerah Khusus Ibu Kota Jakarta, berdampak pada aktifitas masyarakat yang terkait dengan kegiatan di kota Jakarta, baik kegiatan perekonomian, sosial, budaya, keagamaan, dan pendidikan. PSBB ini akan berdampak terhadap semua sektor bisnis di Jakarta. Utamanya bagi sektor-sektor yang bukan bergerak dalam penyediaan kebutuhan dasar publik sebagaimana yang diatur dalam Peraturan Menteri Kesehatan (Permenkes) nomor 9 tahun 2020 tentang pedoman PSBB. Dampak Pertama hampir merata ke semua sektor, mulai dari perkantoran, sekolah, tempat keagamaan, tempat wisata, pertokoan, transportasi dan fasilitas umum lainnya.

Dalam laporan BPS Provinsi DKI Jakarta menyebutkan, kebijakan PSBB Jakarta sebagai upaya untuk menahan laju penyebaran Covid-19 hampir menghentikan seluruh aktivitas masyarakat dan berdampak demikian besar pada kinerja ekonomi, bahkan merambah hingga kegiatan sosial. Hal ini bisa dilihat dari realisasi pertumbuhan ekonomi Provinsi DKI Jakarta pada kuartal II-2020, sebagai periode yang mencerminkan dampak kebijakan PSBB Jakarta pada April-Mei lalu. Data Badan Pusat Statistik (BPS) Provinsi DKI Jakarta menunjukan, realisasi produk domestik regional bruto (PDRB) ibu kota pada kuartal II-2020 minus 8,22\% year on year (yoy). Pencapaian pada April-Juni ini merosot tajam bila dibandingkan dengan Januari-Maret 2020 dengan realisasi sebesar 5,06\% yoy.Ekonomi Jakarta pada kuartal II-2020 lalu pun menjadi yang terendah selama kurun waktu 10 tahun terakhir. Meskipun tidak sedalam saat krisis ekonomi tahun1998.

Penurunan kinerja perekonomian tersebut telah melemahkan daya beli masyarakat dan menyebabkan menurunnya konsumsi rumah tangga. BPS menilai, tingkat inflasi yang terkendali dengan baik tidak cukup mampu mengimbangi penurunan pendapatan masyarakat, sehingga pengeluaran konsumsi rumah tangga (PKRT) terkontraksi cukup dalam sebesar minus 5,23\% yoy dan tidak mampu lagi menjadi penggerak perekonomian Jakarta. Sedangkan pada dampaknya kemiskinan, melemahnya perekonomian akan diikuti oleh pemutusan hubungan kerja (PHK) dan rontoknya sektor informal. Akhirnya menyebabkan penurunan daya beli yang signifikan.

PSBB sebagai langkah pencegahan penyebaran covid-19dilaksanakan selama masa inkubasi terpanjang ini memberikan dampak yang besar terutama bagi kalangan masyarakat 
menengah ke bawah. Kebijakan yang diterapkan Pemerintah DKI Jakarta, seperti pisau bermata dua. Sisi pertama pemerintah memiliki kewajiban untuk melindungi warganya dari penyebaran virus corona. Tapi, disisi kedua, pemerintah memiliki kewajiban untuk membuat roda perputaran ekonomi tetap berjalan. Dengan mempertimbangkan dampak PSBB maka pelayanan sosial di GOR Tanah Abang merupakan langkah konkrit untuk pencegahan penyebaran virus juga mencegah dampak ekonomi dan sosial masyarakat, terutama bagi Penyandang Masalah Kesejahteraan Sosial.

\section{B. TINJAUAN PUSTAKA}

\section{Covid-19}

COVID-19 adalah penyakit yang disebabkan oleh Virus Severe Acute Respiratory Syndrome Coronavirus 2 (SARS-CoV-2). COVID-19 dapat menyebabkan gangguan sistem pernapasan, mulai dari gejala yang ringan seperti flu, hingga infeksi paru-paru, seperti pneumonia. COVID-19 (coronavirus disease 2019) adalah jenis penyakit baru yang disebabkan oleh virus dari golongan coronavirus, yaitu SARS-CoV-2 yang juga sering disebut virus Corona. World Health Organization (WHO) telah menyatakan bahwa virus corona sebagai penyakit pandemi yang dapat diartikan sebagai situasi di mana penyakit menyebar dengan sangat cepat dan meluas ke seluruh dunia. WHO juga menjelaskan bahwa penyebaran virus corona bisa melalui penularan dari orang yang telah terinfeksi virus corona serta sudah dinyatakan positif.

Tingkat Kematian Akibat COVID-19, menurut data yang dirilis Gugus Tugas Percepatan Penanganan COVID-19 Republik Indonesia, Dari seluruh penderita COVID-19 yang meninggal dunia, $0.9 \%$ berusia $0-5$ tahun, $1,8 \%$ berusia $6-18$ tahun, $6,1 \%$ berusia $19-$ 30 tahun, $15,4 \%$ berusia $31-45$ tahun, $35,8 \%$ berusia $46-59$ tahun, dan $40 \%$ berusia 60 tahun ke atas. Sedangkan berdasarkan jenis kelamin, 56,6\% penderita yang meninggal akibat COVID-19 adalah laki-laki dan 43,4\% sisanya adalah perempuan. Faktor Risiko COVID-19 dapat menginfeksi siapa saja, tetapi efeknya akan lebih berbahaya atau bahkan fatal bila menyerang orang lanjut usia, ibu hamil, perokok, penderita penyakit tertentu, dan orang yang daya tahan tubuhnya lemah, seperti penderita kanker.

\section{PSBB}

Pembatasan Sosial Berskala Besar adalah pembatasan kegiatan tertentu penduduk dalam suatu wilayah yang diduga terinfeksi Corona Virus Disease 2019 (COVID-19) sedemikian rupa untuk mencegah kemungkinan penyebaran Corona Virus Disease 2019 
(COVID-I9). Untuk dapat ditetapkan Pembatasan Sosial Berskala Besar, suatu wilayah provinsi/kabupaten/kota harus memenuhi kriteria sebagai berikut: a. jumlah kasus dan/atau jumlah kematian akibat penyakit meningkat dan menyebar secara signifikan dan cepat ke beberapa wilayah; dan b. terdapat kaitan epidemiologis dengan kejadian serupa di wilayah atau negara lain.

\section{Peran Pekerja Sosial}

Menurut International Federation of Social Workers Pekerjaan sosial adalah profesi yang berkaitan dengan praktik kerja dan akademi yang mengenalkan tentang perubahan sosial, pengembangan sosial, kohesi sosial, pemberdayaan masyarakat, dan pembebasan masyarakat. Prinsip utama dalam pekerjaan sosial adalah keadilan sosial, hak asasi manusia, tanggungjawab kolektif, dan menghormati perbedaan. Ada sejumlah peran yang dapat dilakukan oleh pekerja sosial dalam melaksanakan tugasnya antara lain sebagai, konselor, fasilitator, edukator, edvocate, manager, broker, perencana sosial, peneliti, tenaga ahli dan sebagai aktivis, dalam penelitian ini dibatasi 4 peran pekerja sosial antara lain:

a. Peran Konselor, dalam peran konselor, pekerja sosial membantu klien mengungkapkan kebutuhan mereka, mengklarifikasi masalah mereka, mengeksplorasi strategi penyelesaian, dan menerapkan strategi intervensi untuk mengembangkan dan memperluas kapasitas klien untuk menangani masalah mereka secara lebih efektif. Fungsi utama dari peran ini adalah untuk memberdayakan orang dengan menegaskan kekuatan pribadi dan kapasitas klien untuk menangani masalah mereka secara lebih efektif.

b. Peran Edukator atau Pendidik dalam peran pendidik, pekerja sosial terlibat dalam mengajar orang tentang sumber daya dan bagaimana mengembangkan pengetahuan dan keterampilan tertentu seperti menjaga kesehatan, disiplin pengasuhan anak, komunikasi yang efektif, makna diagnosis medis, dan pencegahan kekerasan.

c. Manajer Kasus dalam peran sebagai Manajer kasus, pekerja sosial menempatkan layanan dan membantu klien untuk mengakses layanan sosial. Manajemen kasus sangat penting untuk situasi yang kompleks bagi tunawisma, anak-anak yang rentan, lanjut usia, orang yang memiliki masalah kesehatan fisik atau mental kronis, penyandang cacat, korban kejahatan domestik atau kekerasan lainnya.

d. Fasilitator dalam peran ini, para pekerja sosial terlibat dalam memfasilitasi dan menghimpun kelompok orang bersama untuk berbagai tujuan termasuk 
pengembangan masyarakat, advokasi diri, organisasi politik, dan perubahan

kebijakan. Pekerja sosial terlibat sebagai terapis kelompok dan atau individu.

\section{METODE}

Penelitian ini mengunakan pendekatan kualitatif. Menurut Moleong (2011), penelitian kualitatif yaitu penelitian yang bermaksud untuk memahami fenomena tentang apa yang dialami oleh subjek penelitian secara holistik, dan dengan cara deskripsi dalam bentukkatakata dan bahasa, pada suatu konteks khusus yang alamiah dan denganmemanfaatkan berbagai metode ilmiah. Metode kajian ini dilakukan dengan wawancara, studi literatur dan yaitu mempelajari kepustakaan baik berbentuk laporan pekerja sosial, buku, journal, dan berita media online yang terkait dengan dampak PSBB. Subyek penelitian adalah pekerja sosial yang bertugas sebanyak 14 orang terdiri dari Pekerja Sosial Perlindungan Anak terhadap pekerja sosial yang bertugas di lokasi penelitian yaitu GOR Tensin Tanah Abang Jakarta Pusat yang bekerja di bawah Kementerian Sosial Republik Indonesia. Pada penelitian ini menggunakan pendekatan deskriptif, dimana peneliti berusaha mendeskripsikan, menguraikan, dan menggambarkan tentang Peran Pekerja Sosial dalam penanganan PMKS yang terdampak pelaksanaan PSBB di DKI Jakarta.

\section{HASIL DAN PEMBAHASAN}

\section{Pelaksanaan Pelayanan Sosial bagi PMKS Terdampak PSBB}

Pelayanan Sosial bagi PMKS di GOR Karet Tengsin Tanah Abang merupakan program pelayanan sosial yang ditujukan untuk membantu individu atau kelompok Penyandang Masalah Kesejahteraan Sosial yang terdampak pelaksanaan PSBB yang bertujuan mencegah penyebaran covid-19, mengembalikan dan mengembangkan fungsi sosial PMKS yang terjaring dalam razia. Program tersebut untuk mencegah dampak lebih jauh dari pelaksanaan PSBB agar tidak menimbulkan masalah sosial, seperti kemiskinan, ketelantaran, dan bahkan kriminalitas.

Pelayanan sosial yang diselenggarakan ini melibatkan pekerja sosial yang bertugas menghubungkan PMKS dengan sistem yang menyediakan layanan, sumber daya, dan peluang yang dibutuhkan. Layanan yang diberikan di bawah praktik manajemen kasus pekerjaan sosial berada tersebut di bawah institusi Kementerian Sosial Republik Indonesia dan Dinas Sosial DKI Jakarta. Pelayanan yang diberikan bagi PMKS di GOR Tanag Abang tersebut diharapkan dapat mencegah penularan covid-19, menjamin PMKS yang mempunyai masalah akan memperoleh pelayanan yang dibutuhkannya secara cepat dan tepat. Dengan 
beragamnya jenis masalah yang dihadapi klien di GOR Tanah Abang, maka pekerja sosial dituntut melaksanakan fungsi dan perannya guna memaksimalkan pertolongan yang akan diberikan bagi PMKS Terdampak PSBB.

Data Seluruh PMKS yang dilayani di GOR Tanah abang dari tanggal 24 April hingga tanggal 8 Juni 2020 sebanyak 744 (Tujuh ratus empat puluh empat) orang terdiri dari usia anak-anak atau dibawah delapan belas tahun sebanyak 82, usia dewasa sebanyak 552 orang dan 110 orang berusia lanjut (di atas 60 tahun).

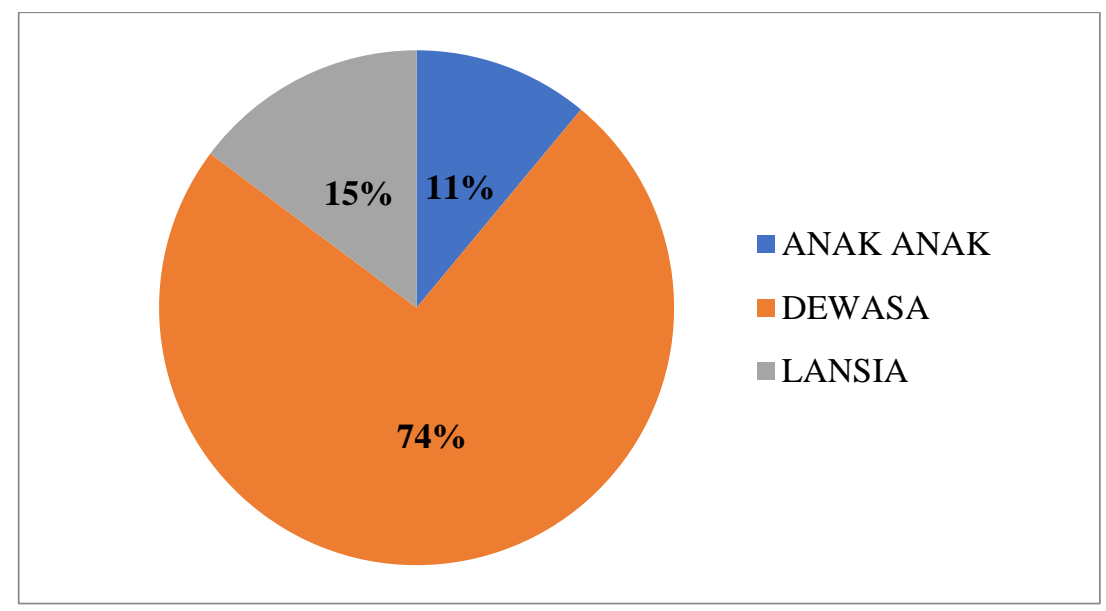

\section{Grafik 1 Data PMKS di GOR Tanah Abang}

Adapun tahapan mekanisme dalam Pelayanan Sosial bagi PMKS di GOR Karet Tengsin Tanah Abang dapat dilihat pada gambar 1 berikut ini:

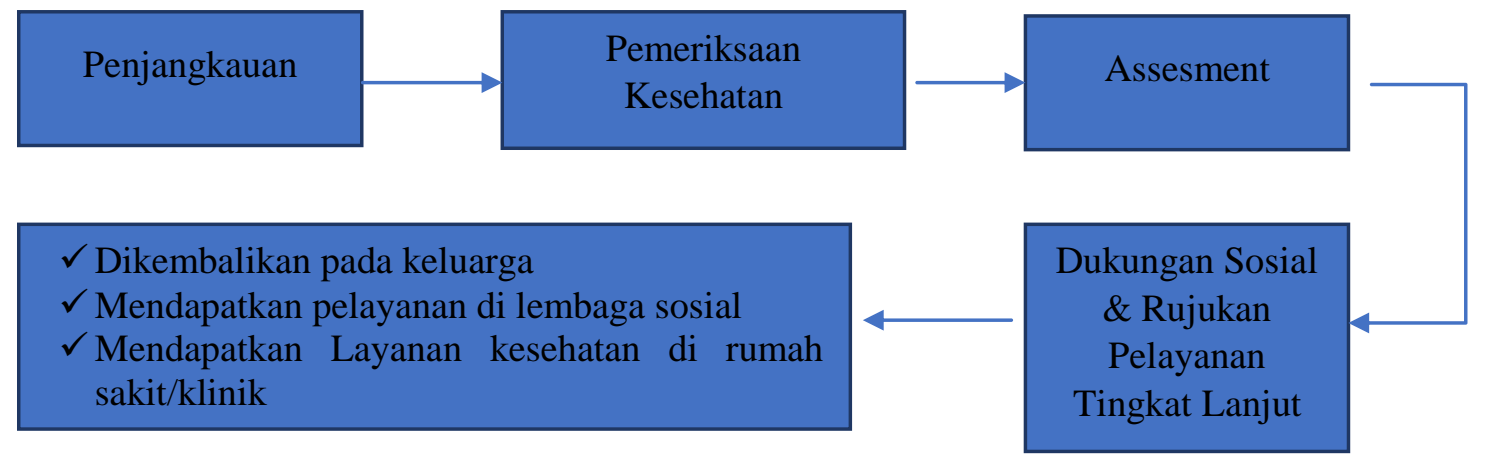

\section{Gambar 1 Mekanisme Pelayanan di GOR Tanah Abang}

Berdasarkan gambar di atas, diketahui bahwa langkah dalam pelayanan PMKS adalah sebagai berikut: Pertama, penjangkauan PMKS oleh Satuan Polisi Pamong Praja (Satpol PP) DKI Jakarta, dalam menangani Penyandang Masalah Kesejahteraan Sosial (PMKS) Jalanan, Dinas Sosial Provinsi DKI Jakarta diharuskan melakukan Penjangkauan secara persuasive, tidak diperkenankan melakukan kekerasan fisik maupun verbal, dari hasil penjangkauan tersebut PMKS ditampung oleh pemda DKI Jakarta di beberapa GOR Wilayah Jakarta Pusat, Jakarta Timur, Jakarta Selatan, Jakarta Utara dan Jakarta Barat. Adapun PMKS yang ditampung itu terdiri dari pengemis, pemulung, pengamen, juru parkir liar, orang terlantar, 
ODMK (Orang Dengan Masalah Kejiwaan), dan lainnya. Selama ditampung di GOR, Pemprov DKI Jakarta menjamin kebutuhan makan para PMKS. PMKS juga harus jalani pemeriksaan kesehatan awal guna mengetahui apakah mengidap gejala Covid-19 atau tidak. PMKS dan tunawisma yang terjaring langsung menjalani asesmen, Hasil asesmen itu yang menjadi rujukan untuk pelayanan selanjutnya, untuk pelayanan yang terbaik untuk nantinya mendapat tindak lanjut pelayanan dari petugas.

Penyandang Masalah Kesejahteraan sosial yang mendapatkan pelayanan sosial di GOR Tanah abang DKI Jakarta, selain mendapatkan dukungan psikososial juga mendapatkan layanan sosial. Layanan tersebut disediakan dan direkomendasikan sesuai kebutuhan PMKS setelah mendapatkan assesment dari pekerja sosial yang melakukan identifikasi kebutuhan klien, ada beberapa rujukan yang akan direkomendasikan oleh pekerja sosial bagi PMKS setelah mendapatkan layanan assesment antara lain dikembalikan pada Keluarg, dirujuk kebeberapa tempat layanan sosial dan kesehatan, antara lain di Balai Rehabilitasi Sosial Eks Gelandangan dan Pengemis (BRSEGP) Pangudi Luhur Bekasi, Balai Rehabilitasi Sosial Watunas Mulya Jaya atau PSKW Mulya Jaya Jakarta Timur, Rumah Sakit Umum Daerah (RSUD) Tarakan, Rumah Sakit Duren Sawit, Panti Sosial Bina Insan (PSBI) Budi Daya 2 Cipayung Cipayung Jakarta Timur, Panti Sosial Tresna Werdha Budi Mulia (PSTW BM) 1 Cipayung Jakarta Timur, Panti Sosial Tresna Werdha Budi Mulia (PSTW) 3 Ciracas Jakarta Timur, Panti Sosial Tresna Werdha Budi Mulia (PSTW) 2 Cengkareng Jakarta Barat, Panti Sosial Asuhan Anak (PSAA) Putra Utama 1 Klender Jakarta Timur, Panti Sosial Asuhan Anak (PSAA) Putra Utama 1 Duren Sawit Jakarta Timur, Panti Sosial Asuhan Anak (PSAA) Balita Cipayung Jakarta Timur, Panti Sosial Bina Insan (PSBI) Budi daya 1 Kedoya, Sasana Perlindungan Semper, Panti Bhakti Kasih, Balai Rehabilitasi Sosial Penyandang Disabilitas Sensorik Rungu Wicara (Balai RSPDSRW) Melati Jakarta Timur, Panti Sosial Bina Grahita (PSBG) Belaian Kasih Jakarta Barat, GOR Senen dan Panti Sosial Bina Karya Harapan Jaya (PSBKHJ) Balaraja. Berikut adalah jumlah PMKS berdasarkan penempatan lokasi rujukan bagi PMKS untuk mendapatkan layanan selanjutnya. 


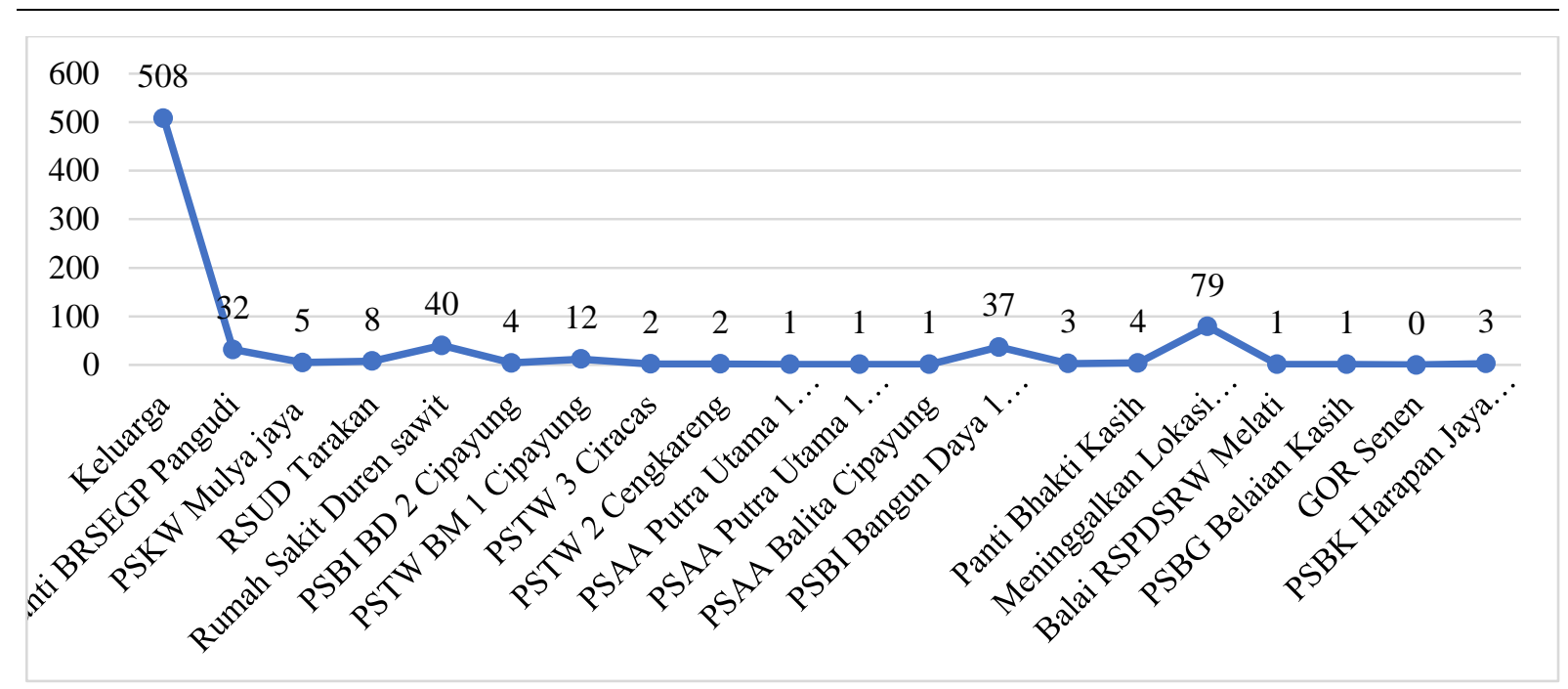

\section{Grafik 2 Data PMKS berdasarkan Lokasi Rujukan}

Sumber: Data Dinas Sosial DKI Jakarta (2020)

Berdasarkan grafik 2 di atas, diketahui bahwa data PMKS yang dijangkau sebanyak 744, sebagaian besar dipulangkan dan dikembalikan kepada keluarga berjumlah 503 orang, adapun tujuan dari pemulangan ini adalah menyelamatkan PMKS yang ada di jalan dari situasi menggelandang, mengemis, dan menghindari terpapar dari Covid-19, untuk dikembalikan kepada keluarga agar mendapatkan perlindungan. Karena dengan kembalinya kepada keluarga, tentu mereka akan menjadi lebih baik sementara PMKS sisanya sebanyak 241 orang dirujuk sesuai klasifikasi, ada yang ke Panti Sosial atau ke rumah sakit sesuai kebutuhan klien. Sementara itu ada yang meninggalkan lokasi tanpa keterangan sebanyak 79 orang.

\section{Peran Pekerja Sosial dalam Pelayanan Sosial bagi PMKS Terdampak PSBB}

Pekerjaan sosial merupakan kegiatan profesional untuk membantu individu-individu, kelompok-kelompok dan masyarakat guna meningkatkan atau memperbaiki kemampuan mereka dalam berfungsi sosial serta menciptakan kondisi masyarakat yang memungkinkan mereka mencapai tujuan (Sukoco (1995:7).

Adapun Peran Pekerja Sosial dalam Pelayanan Sosial bagi PMKS yang Terdampak PSBB di GOR Tanah Abang dapat dijelaskan sebagai berikut:

a. Manager Kasus (Case Manager)

Pekerja Sosial yang bertugas di GOR Tanah Abang berperan sebagai Manager Kasus, peran yang dilakukannya sangat startegis dalam memberikan layanan kepada PMKS yang terdampak pelaksanaan PSBB. Sebagai manager kasus pekerja sosial berkoordinasi dengan berbagai pihak yang memberikan layanan kepada masyarakat terdampak, di antaranya 
dengan Suku Dinas Sosial Jakarta Pusat, Rumah Sakit, Panti Sosial, P3S (Satgas Pelayanan, Pengawasan, dan Pengendalian Sosial) dan profesi lain. Tentu apa yang dilakukan oleh pekerja sosial sebagai manager kasus di GOR Tanah Abang sesuai dengan National Association of Social Workers (NASW) Standards for Social Work Case Management, yang menyatakan bahwa Manajemen kasus pekerjaan sosial adalah metode penyediaan layanan dimana seorang pekerja sosial profesional menilai kebutuhan klien dan keluarga klien, dengan cara mengatur, mengoordinasikan, memantau, mengevaluasi, dan mengadvokasi berbagai layanan untuk memenuhi kebutuhan kompleks klien. Adapun kegiatan pekerja sosial dalam menangani PMKS di GOR Tanah Abang antara lain:

1) Melakukan Identifikasi klien dan orientasinya (Client Identification and Orientation). Dalam hal ini peran pekerja sosial terlibat dalam identifikasi secara langsung dan menyeleksi PMKS untuk mendapatkan perawatan dan pelayanan yang tepat dan dapat diakses oleh PMKS.

2) Asesmen klien (Client Assessment). Pekerja sosial melakukan assesmen terhadap PMKS dengan mengacu pada pengumpulan informasi dan perumusan asesmen dari kebutuhan-kebutuhan klien, situasi kehidupannya hingga mengapa mereka terjaring dalam razia, dan sumber-sumber yang dapat dimanfaatkan. Dalam hal ini seorang pekerja sosial sebagai manager kasus melakukan penggalian atas potensi yang dimiliki klien PMKS, baik kekuatan dan kelemahannya, mana yang memerlukan pelayanan dan mana yang tidak. Pekerja sosial dalam melaksanakan perannya perlu menyadari kebutuhan komprehensif klien, termasuk kekuatan dan kelemahannya. Selain memahami kebutuha klien pekerja sosial juga menjalin kedekatan dengan tenaga pelayanan yang berada di GOR Tanah Abang yang secara langsung bertugas selama dua puluh empat jam, sehingga dapat memahami perubahan dan kebutuhan PMKS.

3) Pekerja sosial melakukan Rencana Intervensi atau Pelayanan. Pekerja sosial mengidentifikasi pelayanan-pelayanan atau sumber-sumber yang dapat dijangkau untuk membantu penanganan masalah klien. Untuk mendukung hal ini Pekerja sosialtelah memiliki daftar lembaga pelayanan yang siap menerima klien dan memahami berbagai prosedur pelayanan. Untuk itu pekerja sosial memberikan informasi kepada klien dan lembaga yang akan menerima rujukan, menjelaskan tujuan dan fungsi pelayanan yang akan diterima.

4) Melaksanakan koordinasi pelayanan.Pekerja sosial sebagai manajer kasus di GOR Tanah Abangselainmenghubungkan klien dengan sumber-sumber yang sesuai, 
juga melakukan koordinasi diantara sumber-sumber yang akan digunakan oleh klien seperti dengan pihak panti sosial dan rumah sakit, sehingga terjalin komunikasi yang terintegrasi dalam proses pertolongan.

5) Pekerja sosial melakukan Tindak lanjut dan Monitoring pelaksanaan pelayanan. Pekerja sosial memastikan pelayanan yang diperoleh PMKS memang benar-benar diperoleh dengan baik, serta digunakan oleh klien secara tepat. Apabila ditemukan adanya penyimpangan atau ketidaksesuaian, pekerja sosial harus segera mengambil tindakan perbaikan atau memodifikasi rencana pelayanan. Pekerja sosial juga menyelesaikan laporan termasuk didalamnya dokumen klien, kemajuan yang dicapai dalam perkembangan kasus klien, pelaksanaan pelayanan serta kesesuaian terhadap rencana yang telah disusun.

6) Pekerja sosial Mendukung PMKS.Selama masa pelayanan sosial di GOR Tanah Abang pekerja sosial membantu klien dan keluarganya menghadapi masalah, terutama saat pengembalian PMKS ke dalam keluarga. Kegiatan ini diantaranya mengatasi konflik pribadi, konseling, penyediaan informasi, memberikan dukungan emosional, dan melakukan pembelaan atas nama klien untuk menjamin bahwa mereka menerima pelayanan sesuai dengan haknya atau agar mereka dapat diterima kembali ke dalam linkungan keluarga.

b. Konselor

Peran pekerja Sosial sebagai Konselor dalam pelayanan PMKS terdampak PSBB bertugas memberikan pelayanan konsultasi kepada klien yang ingin mengungkapkan permasalahannya. Adapun pengetahuan dan teknik yang diterapkan Pekerja Sosial dalam melaksanakan perannya sebagai konselor antara lain;

1) Pekerja sosial menyadari permasalahan yang dihadapi PMKS serta melihat potensi dan kekuatan yang dimiliki klien. Ia juga harus memberikan alternatifalternatif pemecahan masalah. Dalam melakukan perannya sebagai konselor

2) Pekerja Sosial perlu mengenali lingkungan klien, dengan cara tersebut seorang peksos akan mengerti bagaimana cara berkomunikasi serta memilih pendekatan yang baik yang sesuai keadaan klien, tanpa melanggar norma atau nilai-nilai budaya yang dianut oleh klien.

3) Pekerja Sosial memahami permasalahan klien, bagaimana, kenapa dan mengapa permasalahan tersebut bisa terjadi. Pemahaman terhadap suatu masalah dari seorang klien merupakan langkah yang paling penting dalam diri seorang Peksos dalam melakukan perannya sebagai konselor. 
4) Pekerja sosial menjadi pendengar yang baik. Seorang konselor haruslah menjadi seorang pendengar yang baik bagi kliennya. dimana konselor harus sabar dalam mengerti, melayani, memahami dan mendengarkan setiap keluh kesah dari seorang klienagar sebagai konselor mengerti betul apa yang diinginkan oleh klien.

5) Pekerja Sosial tidak memaksakan kehendak. Dalam mencari informasi dan mengenal dekat permasalahan seorang klien, peksos tidak boleh memaksakan kehendak demi mendapatkan informasi yang lebih. Karena pemaksaan bukanlah cara yang efektif dalam suatu pemecahan masalah. Pembawaan yang santai serta adanya Interaksi yang aktif di antara keduanya merupakan cara efektif dalam mencari informasi serta memperdalam permasalahan tersebut.

6) Pekerja Sosial menggunakan cara yang tepat. Ketika Peksos mengerti, memahami serta kenal tentang lingkungan dan permasalahan seorang klien, peksos mempertimbangkan cara dan strategi yang cocok dan sesuai untuk menyelesaikan masalah dari klien tersebut.

7) Pekerja sosial berempati bukan bersimpati. Simpati merupakan rasa peduli dengan menggunakan emosional, sedangkan dalam memberikan suatu solusi peksos tidak boleh ikut merasakan atau berlebihan dalam memainkan emosinya. Tapi peksos memakai empatinya yaitu dengan menahan rasa emosi serta lebih mementingkan kepada pemecahan masalah yang akan diselesaikannya.

8) Menghargai Proses. Hasil dari pemberian nasehat maupun solusi yang diberikan peksos kepada klien tidak terlihat seketika itu juga. Banyak faktor yang dapat mempercepat maupun memperlambat dari proses pemecahan masalah tersebut. Kerjasama antara konselor danklien sangatlah penting agar mencapai tujuan pemecahan masalah.

9) Pekerja Sosial Menjaga Kerahasiaan Klien. Pekerja Sosialtidak bercerita mengenai klien masalah klien dan menjaga identitas klien dari orang lain, terkecuali jika peksos dan klien telah memiliki persetujuan yang telah disetujui di antara keduanya, atau untuk kepentingan klien bagi proses pertolongan yang melibatkan profesi atau institusi lain.

c. Educator

Peran pekerja sosial sebagai pendidik di GOR Tanah Abang memiliki fungsi untuk memberikan informasi dan pengetahuan kepada klien dalam hal bagaimana mencegah penularan Covid-19, cara menjaga kesehatan, memberikan informasi bagaimana menjalani hidup yang bersih dan sehat di lingkungan GOR dan dikeluarga. Menjadi seorang pendidik 
yang efektif terlebih dahulu harus memiliki cukup pengetahuan dan mampu menjadi komunikator yang baik, sehingga informasi yang disampaikan menjadi lebih jelas dan dipahami oleh klien dan sistem makro lainnya, memberikan pemahaman terhadap orangtua dan perusahaan yang mempekerjakan anak tentang dampak yang akan dirasakan oleh anak apabila perkerja anak baik itu di sektor berbahaya atau tidak. Pekerja Sosial sering terlibat dalam mengajar orang tentang sumber daya dan bagaimana mengembangkan keterampilan tertentu seperti penganggaran, disiplin pengasuhan anak, komunikasi yang efektif, arti diagnosis medis, dan pencegahan kekerasan. Pendidik (educator), dalam menjalankan peran sebagai pendidik, community worker diharapkan mempunyai kemampuan menyampaikan informasi dengan baik dan benar serta mudah diterima oleh individu-individu, kelompokkelompok dan masyarakat yang menjadi sasaran perubahan.

\section{d. Fasilitator}

Fasilitator memberi motivasi dengan cara memberi pujian kepada peserta jika hasil kerjanya baik dan memuaskan. Fasilitator mengelola pelatihan dengan membuat perencanaan pelatihan, menyiapkan ke-butuhan yang diperlukan dalam pelatihan, memastikan keefisienan waktu pelatihan, memantau jalannya pelatihan dan kemajuan tiap peserta.

Fasilitator selalu menunjukkan rasa antusias terhadap topik yang dibahas dalam pelatihan. Fasilitator perlu memiliki pengetahuan yang memadai tentang topik yang menjadi pembahasan. Ia menjiwai persoalan dan bahkan bisa mendorong peserta untuk menyukai topik yang mereka pilih. Tanpa pengetahuan dan keingintahuan fasilitator tentang topik yang dipilih peserta, fasilitator sulit mengapresiasi hasil kerja. Apresiasi hasil kerja peserta merupakan salah satu cara paling efektif untuk bisa membuat peserta menjadi pembelajar yang mandiri. Apresiasi kerja dan gagasan peserta membantu membina hubungan yang kooperatif dan bersahabat kepada peserta. Apresiasi hal-hal yang positif dari peserta memberi dorongan kepada peserta untuk berperan aktif.

Fasilitator harus tetap memberikan reaksi yang positif terhadap pertanyaan peserta. Tetapi kita harus menyadari bahwa tugas lokakarya ini adalah mem-berikan kesempatan peserta mengolah informasi dan pengetahuan lapangan mereka sehingga dapat didokumentasi dan disusun menjadi sesuatu yang mudah dipahami dan masuk akal bagi orang yang membacanya. Untuk itu, tekankan bahwa jawaban yang benar sangat tergantung pada situasi dan konteks masalah yang kita hadapi. Kita harus selalu me-nekankan pemecahan masalah yang disesuaikan dengan konteks kemampuan daerahnya. Jadi respon kita terhadap pertanyaan adalah kembali bertanya kepada peserta tentang kondisi yang terjadi di lapangan. 
Berdasarkan kondisi-kondisi itu, kita membuat rumusan dan meletakkan dalam format isian yang harus diselesaikan.

Peran pekerja sosial sebagai fasilitator dalam Pelayanan di GOR Tanah Abang ini diantaranya dengan melakukan kegiatan sebagai berikut:

1) Melakukan panggilan telepon untuk menghubungkan PMKS dengan fasilitas pelayanan sosial, keluarga PMKS, dan sistem lain untuk membantu PMKS mendapatkan dukungan dari berbagai sumber.

2) Pekerja sosial berkoordinasi dengan multi-profesi dantim bimbingan sosial, menilai dan menentukan kasus prioritas dan melakukan intervensi yang tepat.

3) Dalam kasus situasi luar biasa, pekerja sosial melakukan kunjungan rumah secara langsung, untuk perlindungan dalam pencegahan klien terkucil dari lingkungan.

4) Memberikan dukungan terus menerus kepada PMKS yang mengalami kesulitan dalam mengakses sistem layanan sosial

5) Berpartisipasi dalam dukungan psikososial untuk mendukung kebutuhan khusus PMKS

6) Berkolaborasi dalam menanggapi danmenangani PMKS dalam lingkungan shelter sementara di GOR Tanah Abang Jakarta Pusat, bersama dengan institusi lain seperti Dinas Sosial dan Pemda DKI Jakarta.

\section{E. KESIMPULAN}

Pekerja Sosial dalam masa pandemi covid-19 memiliki peran yang sangat strategis dalam membantu pemerintah dan masyarakat dalam mencegah penyebaran Covid-19, Peran pekerja sosial sebagai Manager Kasus bertanggung jawab untuk mengkoordinasi dukungan bagi PMKS secara perorangan maupun kelompok. Peran Pekerja Sosial Sebagai Konselor adalah memberikan layanan konsultasi bagi PMKS dalam mengungkapkan permasalahan mereka, membantu PMKS mencapai pemahaman tentang drinya dan lingkungannya, serta membantu mereka sehingga mampu membuat keputusan, menemukan solusi dan memilih keputusan yang bagi layanan selanjutnya. Peran Pekerja Sosial sebagai Educator berfungsi sebagai pendidik dan pemberi informasi kepada PMKS berkaitan dengan berbagai hal sesuai dengan permasalahan yang dihadapi dalam hal ini adalah tentang Pandemi Covid-19. Peran Pekerja Sosial sebagai fasilitator dalam pelayanan sosial di Tanah Abang adalah memfasilitasi dan memberi alternatif pemecahan masalah, menjalin hubungan kuat dengan PMKS maupun institusi penyedia layanan. Peran Pekerja Sosial dalam menangani PMKS di GOR Tanah Abang dapat berjalan dengan efektif apabila setiap pekerja sosial dan profesi lain 
yang berkolaborasi memahami peran masing-masing, dengan adanya pemahaman peran profesi disetiap bidang layanan maka tujuan pelayanan cepat tercapai, hasil yang diharapkan sesuai dengan target, dapat meningkatkan rasa tanggung jawab, kedisiplinan dan kerjasama.

\section{DAFTAR PUSTAKA}

http://www.courts.state.ny.us/reporter/webdocs/nasw_standards_socialwork_casemgt.htm

https://regional.kontan.co.id/

http://bps.go.id

IPSPI. (2020). Peran Peksos Dalam Situasi COVID-19. Retrieved from https://ipspiindonesia.com/berita/read/97/peran-peksos-dalam-situasi-covid-19.

Moleong, L. J. (2011). Metodologi Penelitian Kualitatif. Bandung: Remaja, Rosdakarya.

NASW Standards for Social Work Case Management, Prepared by the Case Management Standards Work GroupApproved by the NASW Board of Directors, June 1992

Peraturan Gubernur Daerah Khusus Ibukota Jakarta Nomor 33 Tahun 2020 Tentang Pelaksanaan Pembatasan Sosial Berskala Besar Dalam Penanganan Corona Virus Disease 2019 (Covid-19) di Provinsi Daerah Khusus Ibukota Jakarta.

Peraturan Menteri Kesehatan Nomor 9 Tahun 2020 tentang Pedoman Pembatasan Sosial Berskala Besar Dalam Rangka Percepatan Penanganan Corona Virus Disease 2019 (COVID-19)

Sheafor, B. W., \& Horejsi, C. R. (2003). Techniques and Guidelines for Social Work Practice. Boston: Pearson Education Inc.

Sukoco, H. D. (1995). Introduction to Social Work Practice. Bandung: Remaja Rosdakarya.

Woodside, M. \& McClam, T. (2006). Generalist Case Management. Pacific Grove, CA: Brooks/Cole Thomson. 